\title{
3D MODELLING OF THE NEGRO TOWER FOR ITS COMPREHENSIVE ANALYSIS AND A CONSERVATION PROPOSAL
}

\author{
J. García-León ${ }^{1}$, P. E. Collado Espejo ${ }^{1}$, F. Fantini ${ }^{2}$, F. J.Jiménez González ${ }^{1, *}$ \\ ${ }^{1}$ Polytechnic University of Cartagena, Spain - (josefina.garcia, pedroe.collado)@upct.es, franciscoj.jimenezgonzalez@gmail.com \\ ${ }^{2}$ Università di Bologna, Italy - filippo.fantini2@unibo.it
}

Commission II - WG II/8

KEY WORDS: Tower, 3D Laser Scanner, Photogrammetry, Conservation

\begin{abstract}
:
The Negro Tower, in El Algar, Cartagena (Region of Murcia, Spain), is a building which dates to 1585. It is a tower built in a rural environment, inland from the coast, to alert and protect the population from pirate attacks. It was part of the network of watchtowers and defense posts along the coast of Murcia built between the sixteenth and seventeenth centuries. The tower is protected as a historical monument, but its state of conservation is very poor. For this reason, a comprehensive study has been carried out to ensure its correct restoration and future conservation. Historical and constructive analysis has allowed us to discover the social, cultural and architectural characteristics of the tower. Digital photogrammetry and 3D laser scanning compatible with classic topography have been used for the graphic survey of the tower. All this information has permitted the elaboration of thorough three-dimensional modelling and the proposal of a volumetric recomposition of the tower. The presentation will set out the working methodology followed as well as the important results achieved. This research work aims to contribute to the recognition and correct conservation of the Tower. The graphic survey and the three-dimensional model obtained will allow the recovery of the tower and its integration into the natural environment.
\end{abstract}

\section{INTRODUCTION}

The documentation of heritage is the previous step to carrying out any diagnosis of pathologies, and subsequently, any conservation proposal (Almagro, 2004). In addition, if a threedimensional model is made, it can help to achieve a better understanding of the object under study as a whole and aspects such as the construction techniques used.

It is appropriate to use different techniques to produce such graphic documentation. These techniques can be used in a complementary way, such as convergent terrestrial photogrammetry and laser scanning measurement (Yastikli, 2007; Murphy et al., 2013; Remondino, 2011; Peña -Velasco et al., 2017)

The objective of this research is to use the three-dimensional modelling and documentation of a sixteenth century tower, called the Negro Tower, as the basis for the description and diagnosis of the pathologies found in this tower; now in ruins. The graphic restitution will undoubtedly be useful for a thorough constructive analysis that facilitates the restoration, recovery and enhancement of this cultural asset. At the same time that the three-dimensional model is used, it can be implemented in a better understanding of the construction and basic techniques for a reconstruction proposal of the tower under study. The comparative analysis with other towers of the same period along the Mediterranean will help to define this type of construction and what building techniques were commonly used, so that this study can be applied to the restoration of other defensive towers of similar origin.

\section{STUDY SUBJECT}

The Negro Tower or Arráez Tower in the Algar has its origin in the sixteenth century. This tower was part of the defensive system of watchtowers and defense towers devised by Giovanni Batista
Antonelli and Vespasiano Gonzaga to organise the defense of the entire coast of Murcia. Located in a rural environment and very close to the Mar Menor, it is a fortress tower with visual connection to several coastal towers (García-León et al., 2019). The visibility between towers was crucial because it enabled the establishment of a warning system between them. This system was used to transfer alerts regarding attacks by pirates or other dangers in a rapid manner, through fire or smoke on the deck (Gil, 2017).

The main objective of its construction was to shelter the inhabitants from the surroundings and defend the area from pirate attacks, in addition to receiving and transmitting warnings to and from other watchtowers.

Throughout the sixteenth century, the Mediterranean became a natural border between the Spanish and Turkish empires. This border was subject to constant attacks and invasions by both parties. The North African coasts and the Spanish Mediterranean coastline were the most affected due to their geographical situation. The Spanish Levante suffered a large number of corsair attacks from the Maghreb (Chamber, 1991). The Murcian and Mallorcan coasts were especially damaged; largely because they were not properly defended. For this reason and in view of these events, King Phillip II began a great defense project of the entire Mediterranean coast, especially in the southeastern part of the peninsula and in the Balearic Islands. This network of defense towers was developed during the sixteenth and seventeenth centuries, extending along the Spanish Mediterranean and a large part of the Italian coast.

During the sixteenth century, the defense of the eastern Spanish and Amalfi coasts were especially related. During this time both regions were under Spanish rule, which resulted in an exchange of defensive knowledge and even experts, such as the aforementioned engineer, Antonelli.

* Corresponding author 
Having similar needs, the Amalfi coast constructions were also created by establishing an interrelated defense network with individual buildings that would ensure the sighting of pirate attacks, and allow their visual communication and defense against attackers (Russo, 2009).

The defense plan on the coast of Murcia was structured according to the position of the different towers. The coastal towers were the first line of defense and sighting against incursions. Inland we would find another type of tower, further away from immediate attacks but in direct sight lines, more focused on acting as shelters for villagers. Finally, we would find a defense line further inland, also to offer refuge, but mostly to defend the most important populations. These were areas with great economic activity such as agriculture or mining.

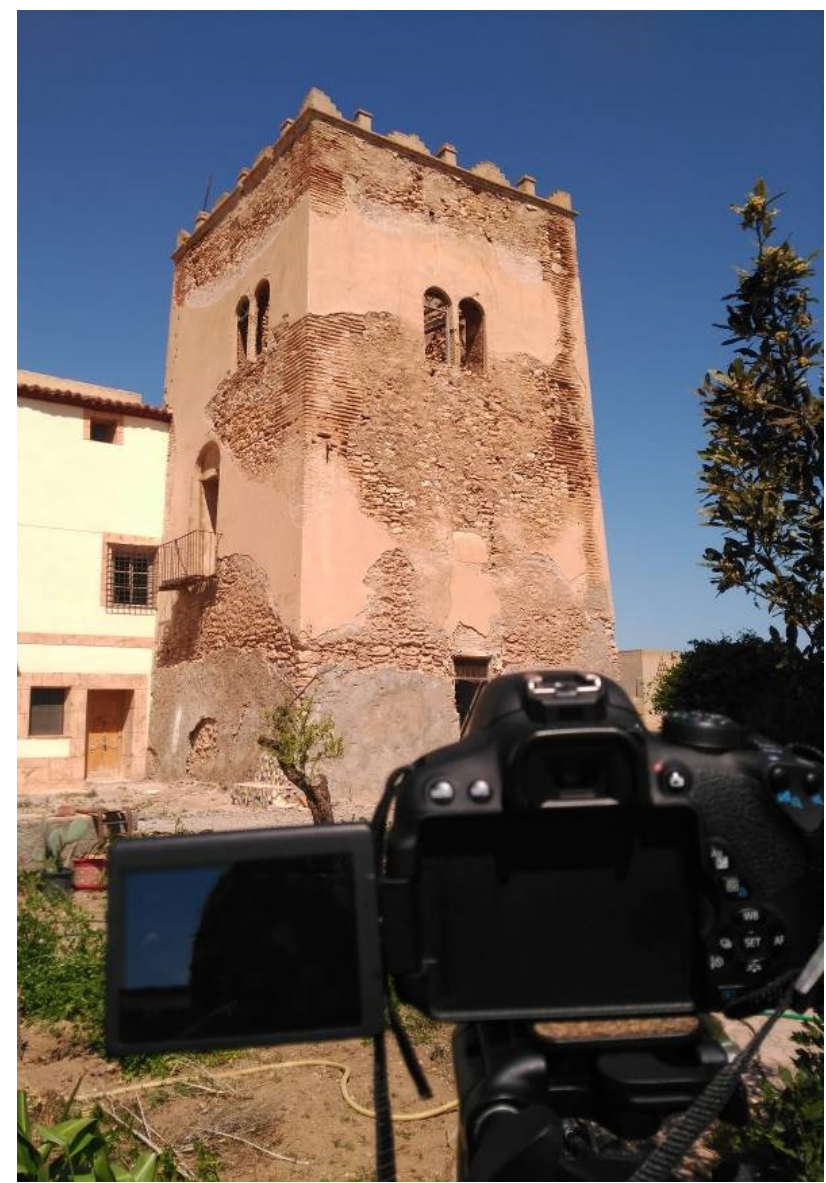

Figure 1. The Negro Tower during the photographic process used for the digital terrestrial photogrametry. Own production.

Depending on location, the tower would have different size, construction and equipment. Coastal towers were equipped with artillery as well as a permanent garrison. Antonelli recommended within his reports to install a minimum of two artillery pieces as well as different types of weapons and ammunition to defend the tower and attacking corsair ships and pirates. Every tower should have their entrance at a height of 3 meters and an internal cistern to self-supply of drinking water (Velasco, 2017). Towers within the second line of defense were dedicated less resources, as they were of less importance regarding the effectivity of the system. Generally, they were larger in size, with a less complex constructive system and almost never well defended. Third line of defense was designed to connect visually with other towers and mostly defend the surrounding area.
The Negro Tower was within the second line of defense. It is based on a square plan with a truncated pyramid shape and an inclination in all its façades. Its structure is based on load-bearing walls which are so stable that they remain standing to their full height today.

Currently the Negro Tower is in a dilapidated state. From its original use as a defense building, it was converted into a residence at the end of nineteenth century. At this time, a private villa was attached to the north and west façades (Figure 1). Furthermore, it has suffered decades of neglect.

\section{DOCUMENTATION AND 3D MODELLING}

Prior to data collection, historical research of the building was carried out. The archived documentation found in the General Directorate of Heritage of Murcia were images of the tower from the 1980s, and a graphic description showing the layout and elevations and several reports on the different pathologies the tower suffered from at that time. Most of the information concerning the Tower comes from the time when it was declared Property of Cultural Interest (hereinafter, PCI). During those years, various studies were carried out by entities such as the Heritage Service of the Region of Murcia or the Department of History of the University of Murcia (General Direction).

It has also been possible to find documentation on the property in the Municipal Archive of Cartagena. A planimetric diagram has been found, probably dating from 1985 . This planimetric diagram contains all the elevations of the tower, with a great amount of detail on its state at that time. As it can be seen in Figure 2, at that time the Tower had widespread pathologies throughout its outer envelope, although it was not in ruins inside (Municipal Archive, 1985). The collapse of the upper deck and the second-floor vault occurred during the 1990s, and there is no proper documentation other than inaccurate oral reports from the inhabitants of the area about this occurrence.

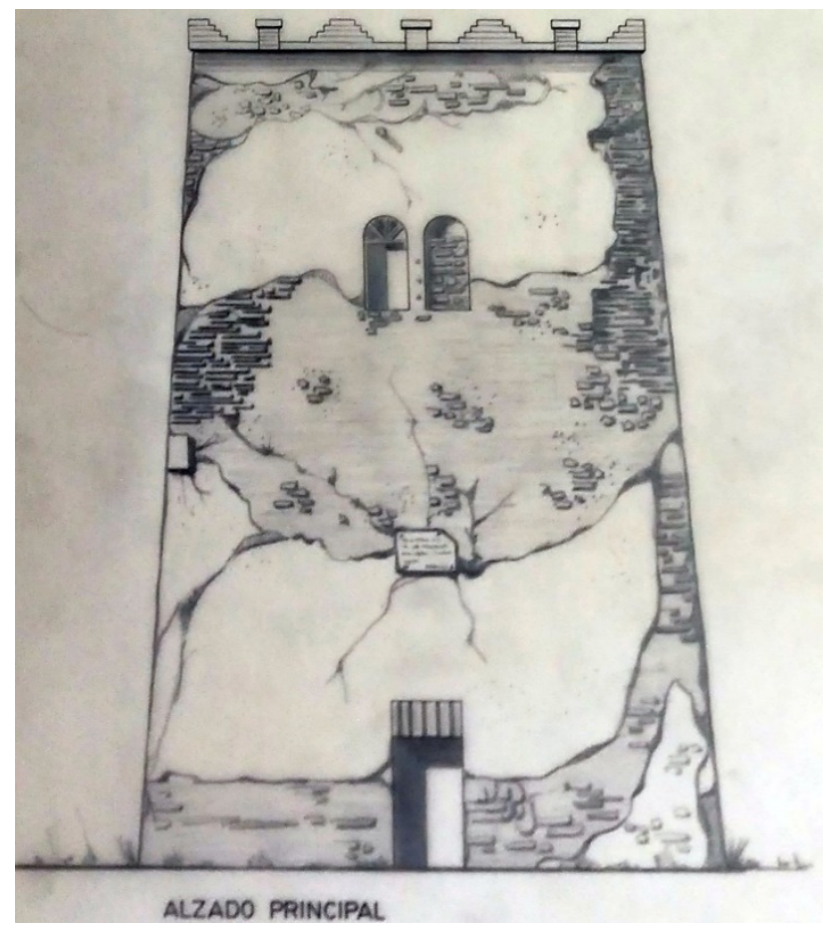

Figure 2. South Elevation of Negro Tower. Hand-made scale drawing. (Cartagena, 1985). 


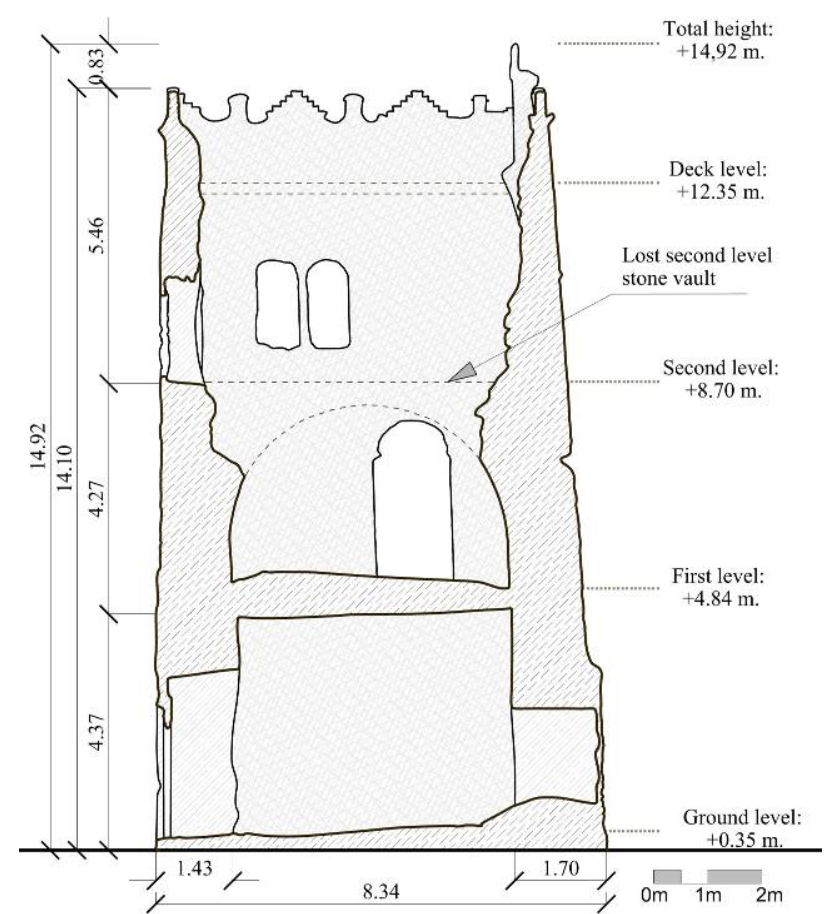

Figure 3. Cross section; north-south direction of the Negro Tower. Current state. Own production.

The tower is currently protected as a PCI under the cultural heritage law of the Region of Murcia. This fact highlights it as a monument to be protected by society and especially by its owners. In addition, legislation limits the possibility of altering the property without the approval of officials specialized in cultural heritage and, among other general conditions, it includes the obligation to make any additions evident in order to avoid erroneous impressions.

As a first step in the modelling process, the Negro Tower was visited several times and measurements were taken in situ. Complementary methods were used in order to obtain a threedimensional model of the tower as a whole using a terrestrial laser scanner, digital terrestrial photogrammetry, and classic topography as a technique to support the laser scanner data. This graphic survey included both the exterior and all the interior spaces of the building. It permitted a general study of the guidelines to be followed for possible future restoration with an accurate metric knowledge of the tower (García-León et al., 2019).

The graphic survey of the Negro Tower made during 2019 and the combination of different three-dimensional modelling techniques opens up many possibilities for the documentation of the tower. The advancement in techniques such as terrestrial laser scanning or digital photogrammetry as added to the collaboration of a multidisciplinary team to analyze the data obtained facilitate the documentation of heritage buildings.

The three-dimensional model enables researchers to obtain several faithful plans to scale that help to understand the construction of the tower. These plans provide accurate measurements of the entire building. In addition to the measurement data, data from missing elements such as the firstfloor vault, or the height of the flat roof have also been deduced (Figure 3). These data are vital for subsequent restoration, since they are the starting point for an intervention that will ensure the survival of the monument.
Through the graphic survey of the interior and exterior not only traditional planimetries have been obtained, such as plans or cross sections of the building, but also three-dimensional images that offer novel views of the Tower (Figure 4). These images verify the type of vault present on the ground floor, the thickness of the walls or the inclination of the same.

The documents produced facilitate the realization of a constructive study of the different elements of the building which helps to discern its possible origin, material, or technique. Crosssectional studies including other contemporary constructions of different regions can then be used for comparison. All these studies are developed without the use of aggressive techniques, respecting the building's value not risking its survival.

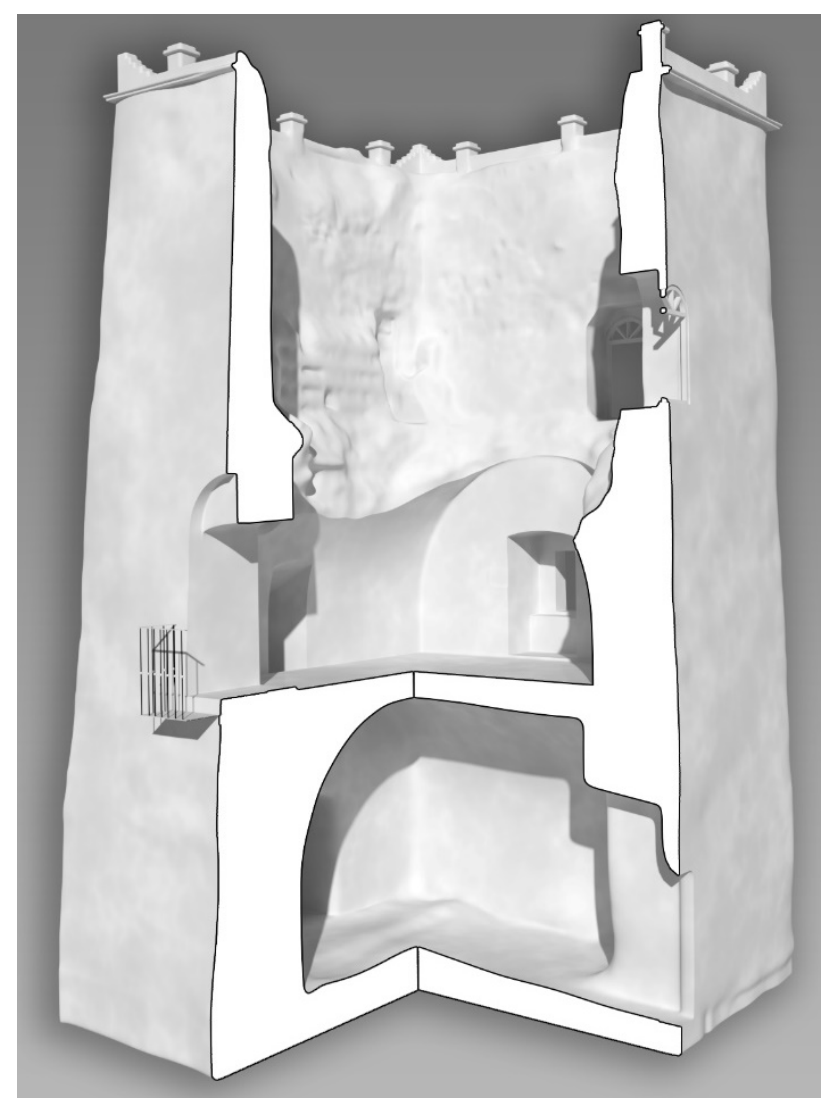

Figure 4. 3D model with cross sections made into it. Own production.

\section{CONSTRUCTIVE AND MATERIAL ANALYSIS}

The construction system of the Negro Tower does not respond to that of an artillery coastal tower, but to that of a safe house. This system was used because its main mission was to protect the inhabitants of the area, and the objective therefore affected the construction process.

With the data of the model obtained, it can be affirmed that it has a truncated pyramid structure with a square base of $8.62 \times 8.62$ meters and a total height of $14.05 \mathrm{~m}$ to the roof battlements. It has two vaults with masonry and cement mortar bases, perpendicular to each other, and an upper deck of a flat slab with wooden beams and interwoven brick. It was built following a system of loadbearing masonry walls, with solid ceramic brick corners and reinforced with great ashlar stones at the base. This constructive analysis is done based on the analysis of collapsed areas of the building, such as first-floor vault and second floor deck. 
As can be seen in Figures 3 and 4, the tower is composed of three levels with a flat roof, having a total constructed area of 234.96 sq. $\mathrm{m}$. There is no communication between the ground and first floors. A general characteristic of this type of tower is the absence of any entrance on the ground floor, with the main entrance on the first floor. The purpose of this is to hinder access to attackers. To gain access, mobile stairs would be available and openings on the ground floor would be avoided at all costs. The communication between the first floor, the second floor, and the roof, was through an internal spiral staircase, made of stone masonry and located in the northwest corner of the building.

The circumstances existing during its execution in 1585 must have affected the materials used during its construction. The tower was built as a safe house, and even with the financing of the city of Cartagena, as evidenced by a marble plaque still visible embedded in its façade, it presents peculiarities compared to the other defensive constructions of its surroundings.

We can see how in the Negro Tower, large carved stones were placed in the corners as reinforcements, as anticipated by Antonelli's plan (Velasco, 2017). However, this reinforcement only exists at the lowest level and is not extended in height, as in the no longer standing Palos Tower or the Almazarrón Tower (García Leon et al., 2018).

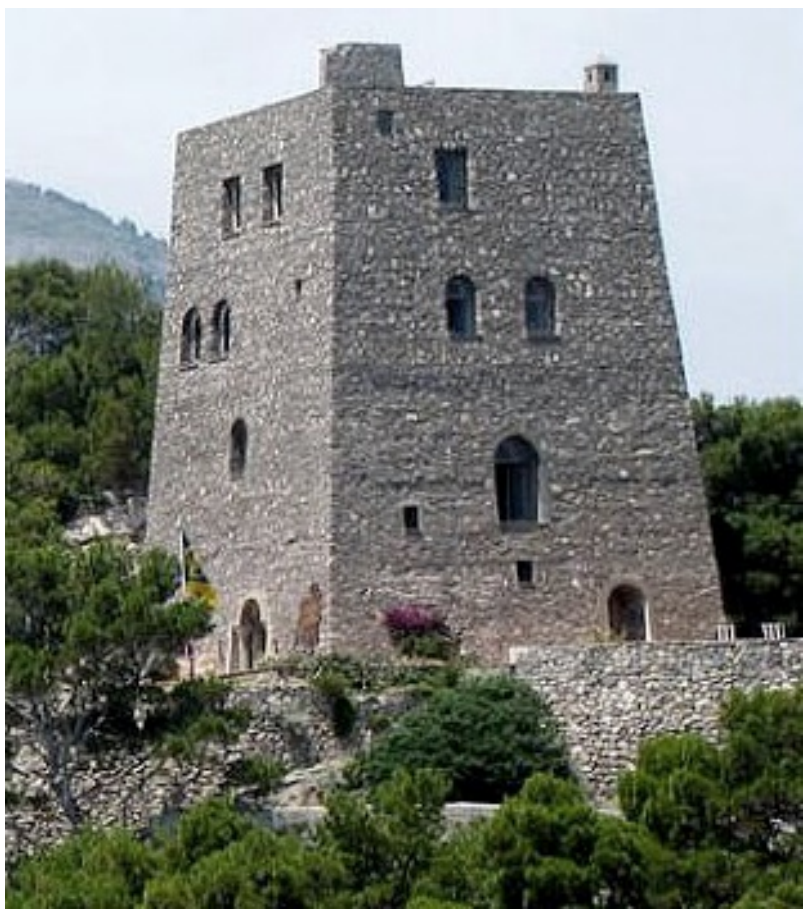

Figure 5 Isola Lunga de Li Galli Tower. (Diaz, 2020).

The truncated conical pyramid shape was used to increase the tower's resistance to attacks. The thickness of the walls on the ground floor is $1.75 \mathrm{~m}$, while at the roof level it is reduced to 0.64 $\mathrm{m}$ wide and an average slope on façades of $5^{\circ}$. Antonelli's plan contemplated a slope at the base of the tower up to a height of $4.17 \mathrm{~m}$, and from there to the top the construction of the rest of the walls would be straight with a thickness of $2.80 \mathrm{~m}$. This type of configuration can be observed in other towers built in the Region of Murcia, such as the Almazarrón Tower, the Santa Elena Tower in the Azohía, or Navidad Tower in Cartagena. Both towers had much more solid structures than that of the Negro or others that, having been built with the same plan, were modified to adapt to the available funds and constructive possibilities.
Similar modification is found regarding the plan of the Tower. The building acquires a square layout, which is easier to build than using one of a circular or hexagonal shape. The hexagonal geometry was the standard for every tower constructed under the plan, because it offers greater constructive guarantees than a square layout as well as an added advantage; it provided greater recoil space for artillery pieces, as Gonzaga pointed out in its defense proposal (Gil, 2017). We can find a square floor in both inland towers such as the Mar Tower, in Burriana, Castellón (Rodríguez-Navarro, 2019) or in the nearby Rame Tower, in the municipality of Los Alcázares and even in the Italian peninsula.

A similar example is found in the restored Aguilo Tower in Villajoyosa, Alicante (Menéndez, 1997). A defensive tower with a square layout of four meters to each side and $8 \mathrm{~m} \mathrm{high,} \mathrm{it} \mathrm{is}$ smaller than our case study; sloped at the base up to $3 \mathrm{~m}$ of height and constructed straight from that point. The entrance can be found high up and it is currently accessed by crossing a small metal bridge. It is totally solid on the ground floor, and the two interior levels are connected. Its construction system is based on perimeter load-bearing walls made of masonry and reinforced with large stone blocks in the corners. This tower has been restored and is currently in good condition. We can see small openings in each façade and two corbels corresponding to a matacan, currently almost disappeared.

Comparing the Negro Tower with different similar examples on the Italian peninsula also brings to light some interesting cases. The Tower in Capo di Praiasciene is interesting to examine and compare to our monument. It was a defending tower of square layout of six meters to each side and $12.67 \mathrm{~m}$ high. Walls were straight from the base with an average thickness of $1.65 \mathrm{~m}$.

Originally, it had three interior levels with an interior connection through a spiral staircase partially embedded in the exterior walls. The entrance was placed high up, with a cistern on the ground floor, accessed directly from the upper floors, which was thought to be resistant to sieges. The tower was extensively modified for habitation by making several openings in its exterior walls and by incorporating a permanent staircase which was nonexistent in the original state (Russo, 2009).

The Isola Lunga Tower is another example similar to our case study (Figure 5). This tower originally had a very similar constructive distribution. It has the shape of a truncated pyramid with a square base each measuring originally $13.94 \mathrm{~m}$ and $14.09 \mathrm{~m}$ and a $14.09 \mathrm{~m}$ high. Its walls were $3.70 \mathrm{~m}$ wide at the base originally, while they currently are $2.30 \mathrm{~m}$ after the renovation it was through.

It had three interior levels, embrasures at the deck level, and like many other towers on the Amalfi Coast, a cistern under the ground level. Later, in the twentieth century, the tower was extensively renovated to adapt it to its new use as a residence and dance studio, with numerous openings and the construction of an intermediate wooden floor.

Like many other coastal towers both in Iberian and Italian peninsulas, Negro Tower was very altered during its adaptation to residential use. A constructive study was made in order to clarify the changes made to the entire building. Nowadays we can find many wide openings at every façade which would probably not exist originally.

The change in use from defensive to residential is evident in the tower under study. Openings have been made in all its façades and levels, such as a balcony on the first floor, windows or entrances on the ground floor, or even the attached country house. All these elements would not originally exist due to defensive reasons. 


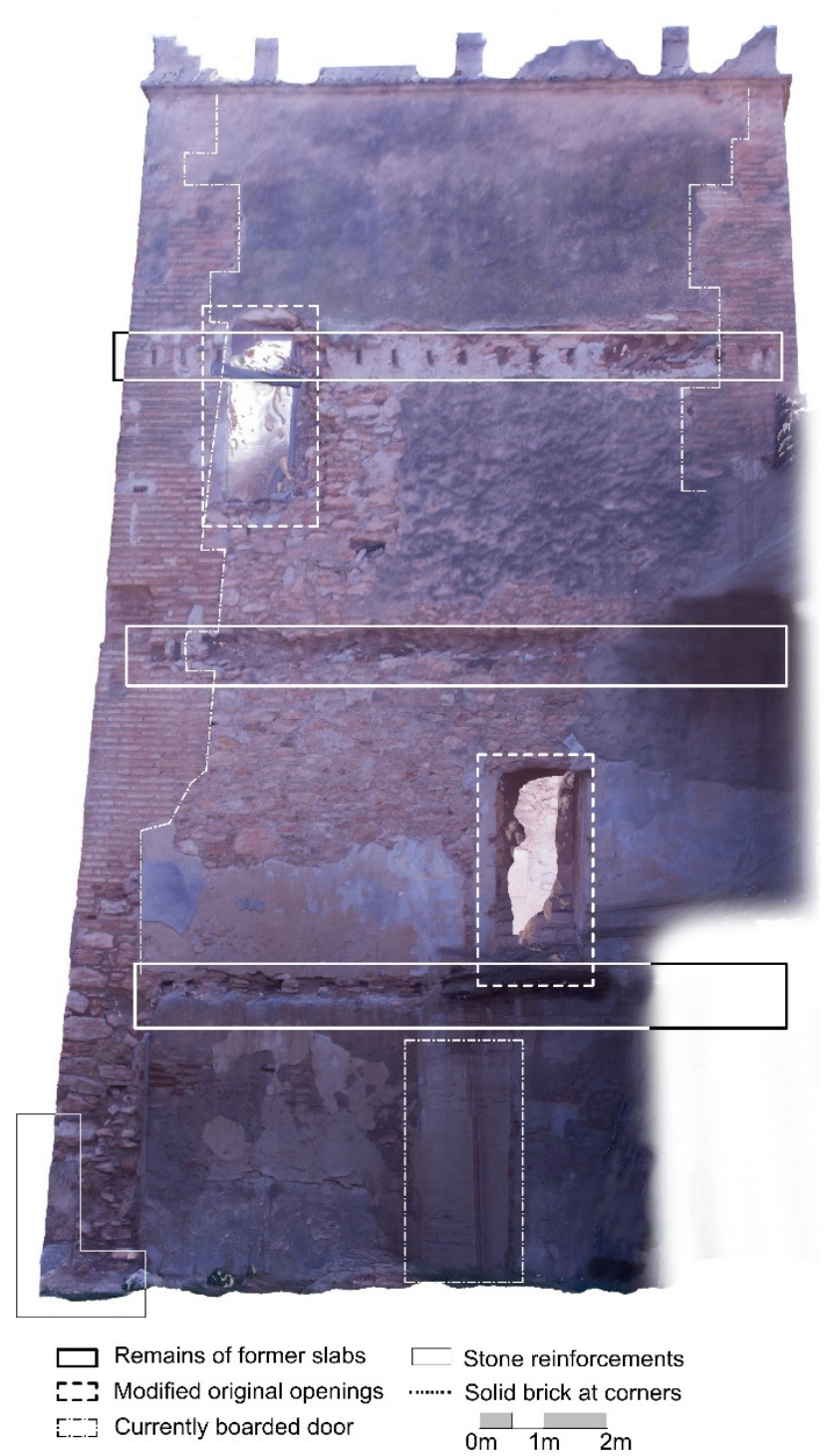

Figure 6. Constructive study of north façade of the Negro Tower. Current State. Own production

Figure 6 shows a part of the construction study carried out; in this case corresponding to the north elevation of the tower. This elevation has been the most affected by the modifications made to attach the country villa. This house collapsed during the 1980s and 1990s, producing obvious damage to this façade. The places where the wooden slabs of the country house were embedded into the tower can be clearly seen. Due to the very poor state of the façade and the total absence of almost any coating, both the stone block reinforcements in the corners and the relationship between the ceramic bricks in the corners and the masonry of the exterior walls are visualized.

The façade openings have also been widely modified. Some openings have survived practically without alterations, like the embrasure on the second floor or the access door on first floor; while window and door openings have been made in the other elevations, mostly taking advantage of former defensive-based openings. The boarded door on the ground floor on the north façade is worth mentioning. It was probably opened during the adaptation to residential use in order to enable communication with the attached house and was nonexistent in the original design (Figure 6).
The current state of conservation of the Tower is very precarious, defined as semi-ruinous. The main deterioration factor has been the lack of proper maintenance for decades as well as elevated exposure to very aggressive weather agents in this coastal area (Collado et al., 2018). This has favored the erosion of the external walls, with widespread landslides and loss of section in masonry and bricks. Corner bricks and hollow jambs exhibit disintegration and sandblasting. In some places the loss of section and deterioration is serious, with wide gaps in the façade plane. Generalized cracks and fissures can be found over the envelope. Although fissures are not worrying and they are just the proof of the worsening state of the building, existing cracks on the external walls are concerning, as they are a real danger of collapse.

All these pathologies have been represented graphically in the pathological study made. An example of this can be seen on the south façade, made with the texture of the photogrammetry model that can be seen in Figure 7, where the different pathologies described have been represented.

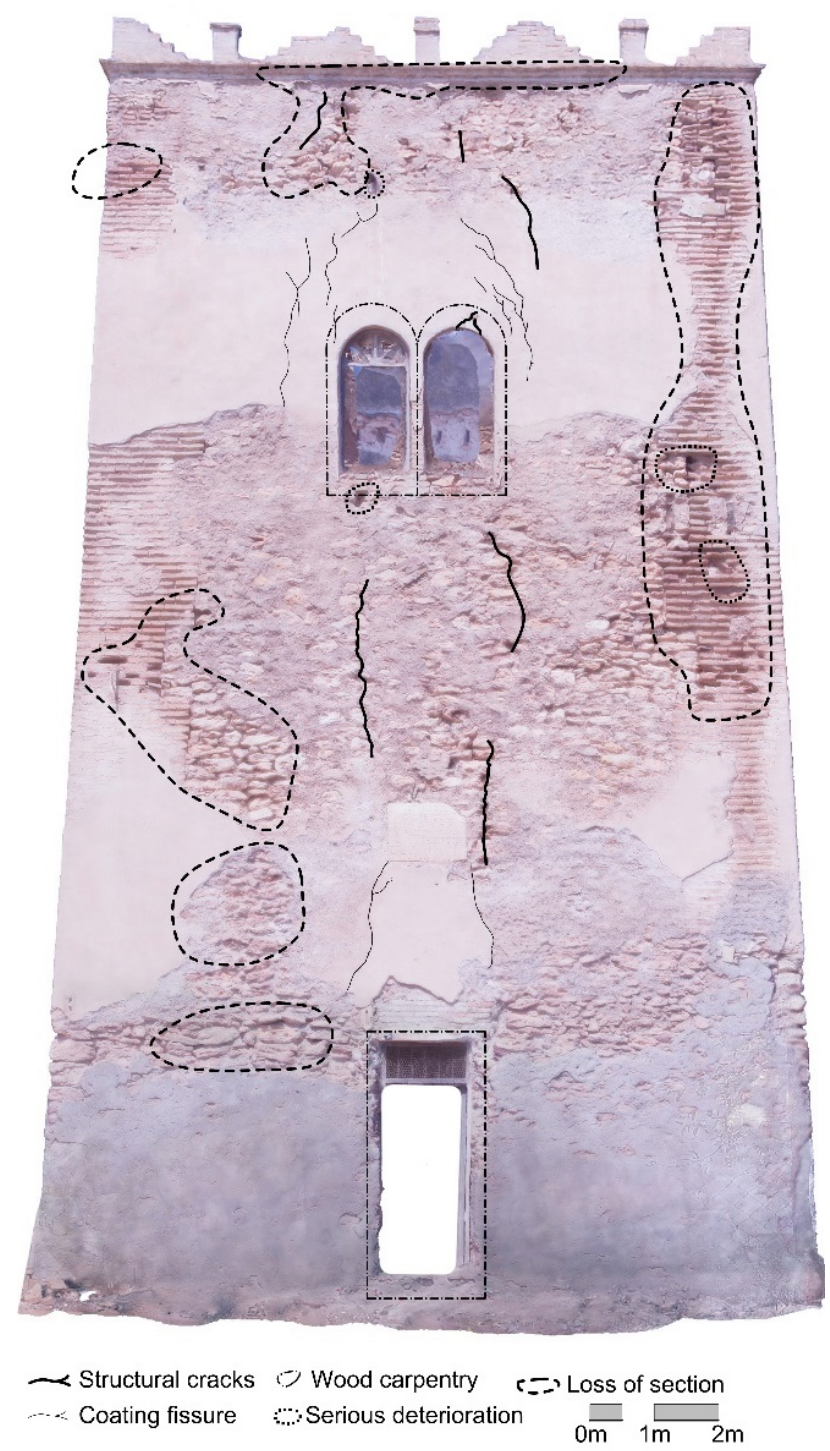

Figure 7. Study of pathologies of south façade of the Negro Tower. Current State. Photogrametry modelling. Own production. 
Interior spaces are not exempt from the general damage of the monument. The ground floor vault is in good condition, but from that point, the entire interior is demolished, with part of the debris remaining over the ground floor vault. As a result of the interior collapse, the internal spiral staircase is not preserved, leaving only traces of its existence. Regarding carpentry, only a fence and the railing of the balcony on the first floor remain. Every forging element presents oxidation and corrosion. The rest of the openings of the envelope (windows and access door on the first floor) are permanently open, without carpentry of any kind.

\section{CONSERVATION PROPOSAL}

The objective of the survey, graphic documentation, and study of the towers coeval to the Negro Tower is to be used for the proposal of architectural restoration and recovery as a building of historical reference within its environment. Thus, the information obtained in the documentation is used to propose a comprehensive restoration project that allows not only its consolidation and general renovation, but also its recovery as a cultural asset, recognized as a monument by the inhabitants and available for tourists to visit.

This proposal is based on a clear strategy: only by bringing the tower back to life, we will ensure it survival in the future. Heritage restoration must include its use by citizens and tourist, avoiding future abandonment. Negro Tower could be an excellent example of defending infrastructure built in Iberic peninsula during 16th and 17th centuries, as well as the history and lifestyle of that time.

The creation of an accessible path from the nearest road as well as the generation of a pleasant outside area for the exterior observation of the building are proposed. The installation of informative panels both outside and inside the tower is proposed for the dissemination of its historical values as well as its historical evolution.

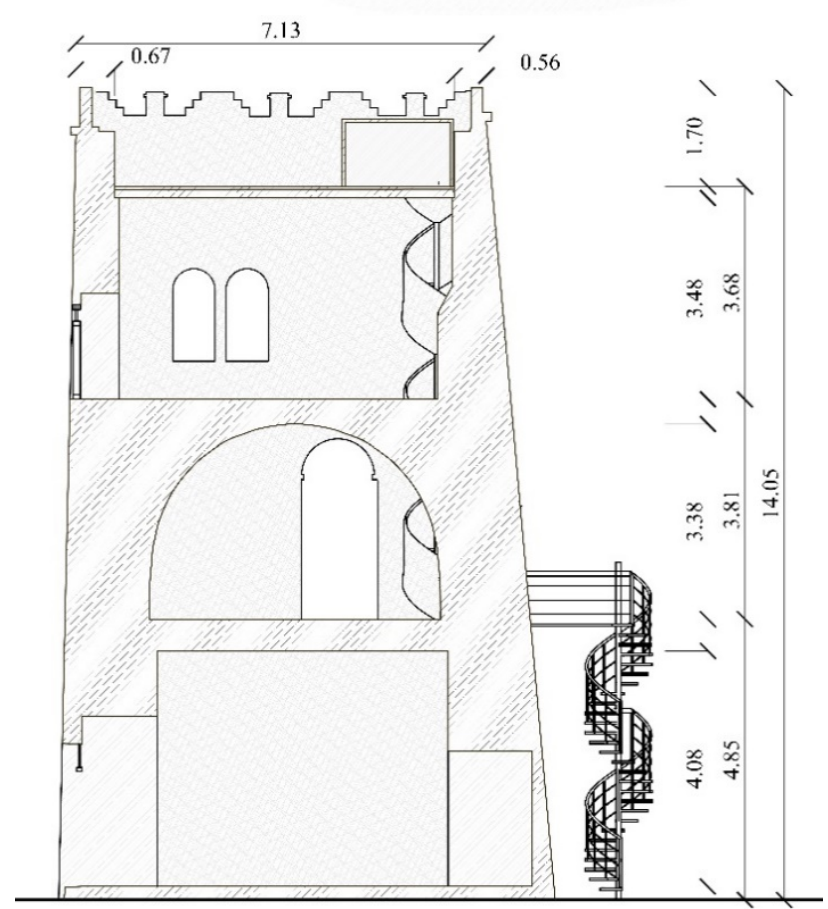

Figure 8. Cross section. Restauration proposal. Own production.
The proposal contemplates the reconstruction of the stone vault of the second floor, the deck slab of wooden beams and interwoven brick, and the interior spiral brick staircase. As a permanent alternative to resolve access to the first floor, an exempt spiral staircase made of weathered steel with a lightweight design is suggested. The proposed staircase will not affect the exterior image of the tower. Although this solution does not include universal accessibility, it has to be bear in mind that the proper conservation of the historical identity of the monument it is very important. (Figure 8).

The restoration project must be carried out in phases for its correct execution, assuring the process will not affect the monument itself. The exterior restoration will be limited to basic cleaning processes -elimination of biodeterioration, deteriorated coating and eroded bricks- and sanitation of the affected areas for the subsequent placement of bricks of similar characteristics and the placement of a final water-repellent coating that will protect it from the aggressive environment in which the monument is located. Finally, it would be white, as it probably was originally.

Regarding the inside spaces, the first-floor vault of solid brick and the wooden roof slab will be rebuilt as well as the interior brick spiral staircase. All lost elements will be reintegrated with traditional building materials and systems. It is absolutely necessary to clean and protect the first-floor fence as well as every existing metal element and proceed with the placement of new wooden carpentry on all the doors, windows, and the firstfloor balcony. It will also be necessary to clean and rebuild the roof battlements that crown the tower.

In order to solve the problem of access to the roof, which is currently not possible, several weathered steel boxes, unseen from external positions will be installed. They have been designed to provide proper covering to the accessing staircase, while, at the same time, not altering the external volume of the Tower.

\section{CONCLUSIONS}

During the 16th and 17th centuries, defensive towers were built on the Mediterranean coast to defend the area against pirate attacks from North Africa. These towers had a similar construction system in both Italy and Spain, with sloped walls which were predominantly built with stone masonry and with punctual reinforcements of ashlarstones and bricks. These towers had crosssectional defensive, shelter, and sighting functions, integrated into coastal defense networks through visual connections between them.

Heritage documentation, including accurate three-dimensional models, allows the use of a proper knowledge-based approach to analyze changes that may have been made both in construction and due to pathology, and subsequently draft conservation or restoration proposals. This information is the base towards the drafting of restoration proposals, trying to assure that the historicalarchitectural identity of the building is respected while at the same time that it is valued by giving it a cultural use.

The study and constructive analysis of towers with different locations facilitates the comparison of constructive methods and maximizes the possibilities of restoration, demonstrating the exchange of information between the Iberian and Italian peninsulas in regard to military architecture.

Negro Tower is currently poorly maintained and in real threat of collapse and disappearance. Its restoration is urgent and basic to restore this architectonical asset but, at the same time, it is a perfect opportunity to put in value this 5-century old monument while disseminating its history. 


\section{REFERENCES}

Almagro, A.,2004. Levantamiento arquitectónico. Universidad de Granada. Granada.

Cámara A., 1991. Las torres del litoral en el reinado de Felipe II: una arquitectura para la defensa del territorio (y II). In Espacio, Tiempo y Forma. Serie VII, Historia del Arte, $\mathrm{n}^{\circ} 4$. UNED, 53-94.

Cartagena municipal archive. Elevation map of Negro Tower and Azohia Tower. 1985 approximate date. Catalog code PL00239. Cartagena, Spain.

Collado, P.E.; García-León, J.; García, J.F., 2018. Estudio integral de la Torre Navidad, en Cartagena (España), para su correcta conservación, puesta en valor y musealización. In Defensive Architecture of the Mediterranean. Vol. IX. Politecnico di Torino, Torino, Italy, pp. 1179-1186.

Díaz, A., In the Mediterranean there is a private dolphin-shaped paradise. Lavozdelmuro.net. 20/01/20.

García León, J., Collado Espejo, P. E., Ramos Martínez, M., Cipriani, L., Fantini, F. 2018. Las torres vigías artilladas de Felipe II en la Región del Murcia. Representación tridimensional virtual de la Torre Navidad. Defensive Architecture of the Mediterranean. Vol. IX. Politecnico di Torino, Torino, Italy, pp. 997-100.

García-León, J., Collado Espejo, P. E., and Jiménez González, F. J. 2019. Negro tower: documentation, conservation, and restoration. Int. Arch. Photogramm. Remote Sens. Spatial Inf. Sci., XLII-2/W15， 489-496. doi.org/10.5194/isprs-archivesXLII-2-W15-489-2019, 2019.

General Direction of Cultural assets of the Autonomous Community of the Region of Murcia. Dossier of Negro Tower. Catalog Code 16257. Murcia, Spain.

Gil, A., 2017. La defensa de la costa de Lorca en los siglos XVI y XVII. In Revista ALBERCA, n ${ }^{\circ}$ 15, Lorca, 169-240.

Murphy, M., McGovern, E., Pavia, S., 2013. Historic Building Information Modelling-Adding intelligence to laser and image based surveys of European classical architecture. ISPRS Journal of Photogrammetry and Remote Sensing $n^{\circ} 76,89-102$.

Menéndez Fueyo, J., 1997. Centinelas de la costa: torres de defensa y de la huerta de alicante. Excma. Diputación Provincial Museo Arqueológico Alicante.

Peña Velasco, M.C., García-León, J., Sánchez Allegue, P., 2017. Geomatic applications to the knowledge, conservation and dissemination of an altarpiece: The Baroque masterpiece of Saint Michael in Murcia (Spain). e-rph: Revista electrónica de Patrimonio histórico. Vol. 21, pp. 67-90. $\mathrm{http}: / /$ www.revistadepatrimonio.es/revistas/numero21/difusion/ estudios/articulo.php4

Remondino, F., 2011. Heritage Recording and 3D Modeling with Photogrammetry and 3D Scanning. Remote Sensing, 3, pp.11041138 .

Rodríguez-Navarro, P., 2019: Torre de la Mar (Borriana), TOVIVA project. https://toviva.blogs.upv.es/torre-de-borriana/, 07.01.2019.
Russo, F., 2009. Le torri costiere del Regno di Napoli: la frontiera marittima e le incursioni corsare tra il XVI ed il XIX secolo. The coastal towers of the Kingdom of Naples: maritime defence and pirate incursions between the XVI and the XIX century. Edizioni scientifiche e artistiche, Napoli: ESA.

Velasco F., 2017. La construcción de torres de defensa en el litoral de Lorca, Mazarrón y Cartagena durante el siglo XVI. In MURGETANA. Año LXVIII, n 136 , Murcia, 57-83.

Yastikli, N., 2007. Documentation of cultural heritage using digital photogrammetry and laser scanning. Journal Cultural Heritage, v. 8 n. 4, pp.432-427. http://www.sciencedirect.com science/article/pii/S1296207407001082 